\title{
A EXPANSÃO URBANA DO PLANO DIRETOR DE PALMAS: UMA ANÁLISE JURÍDICA ACERCA DA DISPUTA DO ESPAÇO URBANO EM PALMAS/TO
}

\section{THE EXPANSION OF THE MASTER PLAN OF PALMAS/TO: A JURIDICAL ANALYSIS ABOVE THE DISPUTE OF THE URBAN SPACE IN PALMAS/TO}

Regina Moreira de Sousa*

\begin{abstract}
RESUMO
O presente trabalho se propõe a discutir a deliberação legislativa da Câmara Municipal de Palmas nos Projetos de Leis Complementares no 06 e 07, bem como a Emenda Substitutiva 001/2012 que dispõem sobre alterações do Plano Diretor. A discussão perpassa pelos principais acontecimentos que permearam 0 debate, como as manifestações contrárias à expansão urbana e a proposição de duas ações civis públicas e uma ação direta de inconstitucionalidade. O objetivo geral desse trabalho é discutir a deliberação legislativa da Câmara Municipal de Palmas acerca das alterações propostas para o Plano Diretor nos anos de 2011 e 2012. Para tanto, desenvolveu-se como metodologia de pesquisa a análise da legislação urbanística em vigor, nas três esferas de governo; a avaliação do trâmite dos processos legislativos na Câmara de Vereadores nos anos de 2011 e 2012; a análise e interpretação dos Projetos de Lei Complementar Municipal sobre urbanismo a partir do ano de 2011 e; a análise dos Processos Judiciais resultantes da discussão da expansão urbana da cidade. O estudo do tema busca contribuir para a compreensão da forma como a cultura política patrimonialista e clientelista influenciou e continua a influenciar no planejamento e na gestão urbana, na elaboração da legislação urbanística e, sobretudo, no modo de ocupação da cidade de Palmas/TO. Tanto é que foi possível inferir que a questão urbana de Palmas nada tem haver com a falta de espaços, mas sim com quem pode ser o dono de certos espaços. Entretanto, a obstinação do poder publico local para praticar e fomentar a especulação imobiliária vê-se, ao menos temporariamente, barrada frente às pressões de grupos sociais contrários à expansão urbana de Palmas/TO.
\end{abstract}

PALAVRAS-CHAVE: Expansão Urbana; Palmas; Plano Diretor

\section{ABSTRACT}

The present work analysis above the dispute of the urban space in Palmas in the Projects of Complementary Law n 06 and 07, as well as the Substitutive Amendment 001/2012 that argues about the alterations in the Master Plan of the city. The discussion pervades the principal happenings that permeated the debate, like the contrary manifestations to the urban expansion and the proposition of two public civil actions and one direct action of unconstitutionality. The general objective of this work is to discuss the legislative deliberation of the City Council of Palmas on the suggested alterations to the Master Plan in the years of 2011 and 2012 . Therefore, it was taken the objective to analyze the urban legislation in force, in the three spheres of government; value the progress of the legislative process in the City Council in the years of 2011 and 2012; analyze and interpret 
the Complementary Law Projects about urbanism starting from the year of 2011 and; analyze and interpret the Judicial Process resulted from the discussion of urban expansion in the city. The study of the subject will contribute to the comprehension of how the patrimonialistculture influenced and has been influencing the urban planning, urban management, the elaboration of the urban legislation and, above all, the way the city of Palmas/TO is occupied. So much so that it was possible to infer that the urban question of Palmas has nothing to do with the lack of space, but who can be the owner of certain spaces. However, the stubbornness of the local public power to practice and encourage real estate speculation is seen, at least temporarily barred the face of pressure from social groups opposed to urban expansion Palmas/TO.

KEY-WORDS: Urban Expansion; Palmas; Master Plan

\section{CONSIDERAÇÕES INICIAIS}

O presente trabalho busca realizar uma análise jurídica acerca da disputa do espaço urbano em Palmas/TO. Para tanto, discute-se a deliberação legislativa da Câmara Municipal de Palmas nos Projetos de Leis Complementares no 06 e 07, bem como a Emenda Substitutiva 001/2012 que dispõem sobre alterações do Plano Diretor. A discussão perpassa pelos principais acontecimentos que permearam o debate acerca do tema, como as manifestações contrárias à expansão urbana expressas pelo Conselho de Desenvolvimento Urbano e Habitação de Palmas e pela Universidade Federal do Tocantins, bem como a proposição de duas ações civis públicas e uma ação direta de inconstitucionalidade.

A fim de compreender a deliberação legislativa da Câmara Municipal de Palmas acerca das alterações propostas para o Plano Diretor nos anos de 2011 e 2012, desenvolveu-se, como metodologia de pesquisa, a análise da legislação urbanística em vigor, nas três esferas de governo; a avaliação do trâmite dos processos legislativos na Câmara de Vereadores nos anos de 2011 e 2012; buscou-se a interpretação dos Projetos de Lei Complementar Municipal sobre urbanismo a partir do ano de 2011.

Inicialmente será apresentado um breve relato do Plano Diretor Participativo de Palmas correlacionando-o ao processo de planejamento e implantação da cidade. A finalidade dessa análise é relatar o modo de ocupação inicial previsto para a cidade a fim de que, posteriormente, se possa fazer um comparativo entre o plano e a realidade ocorrida.

Por fim serão discutidos os projetos de expansão do Plano Diretor de Palmas. Apresenta-se uma correlação dentre os principais acontecimentos a fim de analisar as 
motivações alegadas pelo poder público para justificar os projetos de expansão urbana da cidade. Desse modo, pretende-se confrontar a postura política do Executivo e do Legislativo ante os verdadeiros interesses público-sociais.

\section{O PLANEJAMENTO INICIAL PARA CONSTRUÇÃO E IMPLEMENTAÇÃO DA CIDADE DE PALMAS/TO}

Para definir e organizar a ocupação da área onde seria fundada a cidade de Palmas, foi desenvolvido, inicialmente, um plano urbanístico básico que incluiu o desenho geral das vias, organizando-se entre elas as super quadras que seriam áreas destinadas a residências, ao comércio, à indústria, a equipamentos urbanos (escolas, hospitais, creches, etc.) além das áreas de preservação ambiental, lazer e recreação. (SEGAWA, 1991).

O mapa abaixo, registrado na obra de Bazolli (2012) demonstra a localização da cidade e de seu respectivo perímetro urbano,

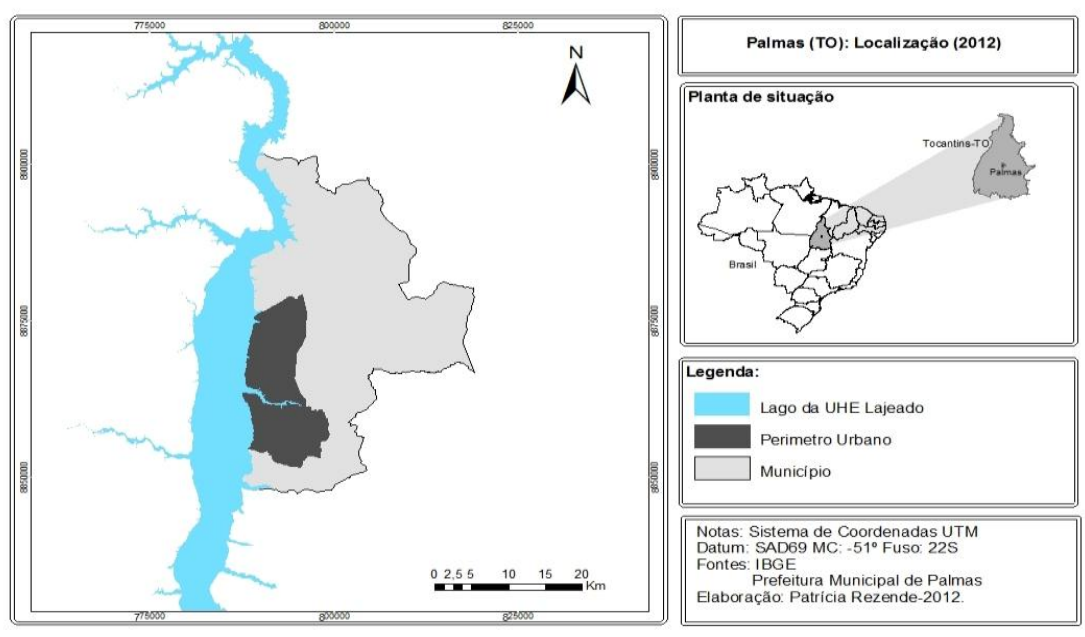

Figura 01: Mapa de localização da cidade de Palmas/TO.

Segundo os autores do projeto, a implantação do plano urbanístico básico previu uma expansão controlada da urbanização de modo que, após aberto o sistema viário básico, as quadras seriam progressivamente implantadas como módulos, conforme 0 aumento da demanda por espaços. Tudo isso respeitando o ritmo do crescimento urbano. O objetivo desse plano básico era evitar e, até mesmo, controlar a dispersão urbana na área total prevista para a cidade a fim de se garantir o aproveitamento racional e econômico de toda a infraestrutura dos serviços públicos. 
A previsão dos planejadores da cidade, era de que na ocupação da área do projeto original de 11.085 hectares destinado a 1,2 milhão de habitantes, fossem, inicialmente, urbanizados 1.624 hectares, área suficiente para acolher uma população de 120 mil habitantes, até o quinto ano da fundação da cidade. Se obedecida a projeção inicial, Palmas teria 200 mil habitantes até o décimo ano, podendo chegar ao 15ำ ano com 800 mil habitantes, sem causar transtornos de ordem social, com uma média de adensamento entre 300 a 350 habitantes por hectare. (BAZOLLI, 2012)

A ocupação da cidade se daria em etapas, obedecendo ao planejamento inicial, conforme observado na figura abaixo:

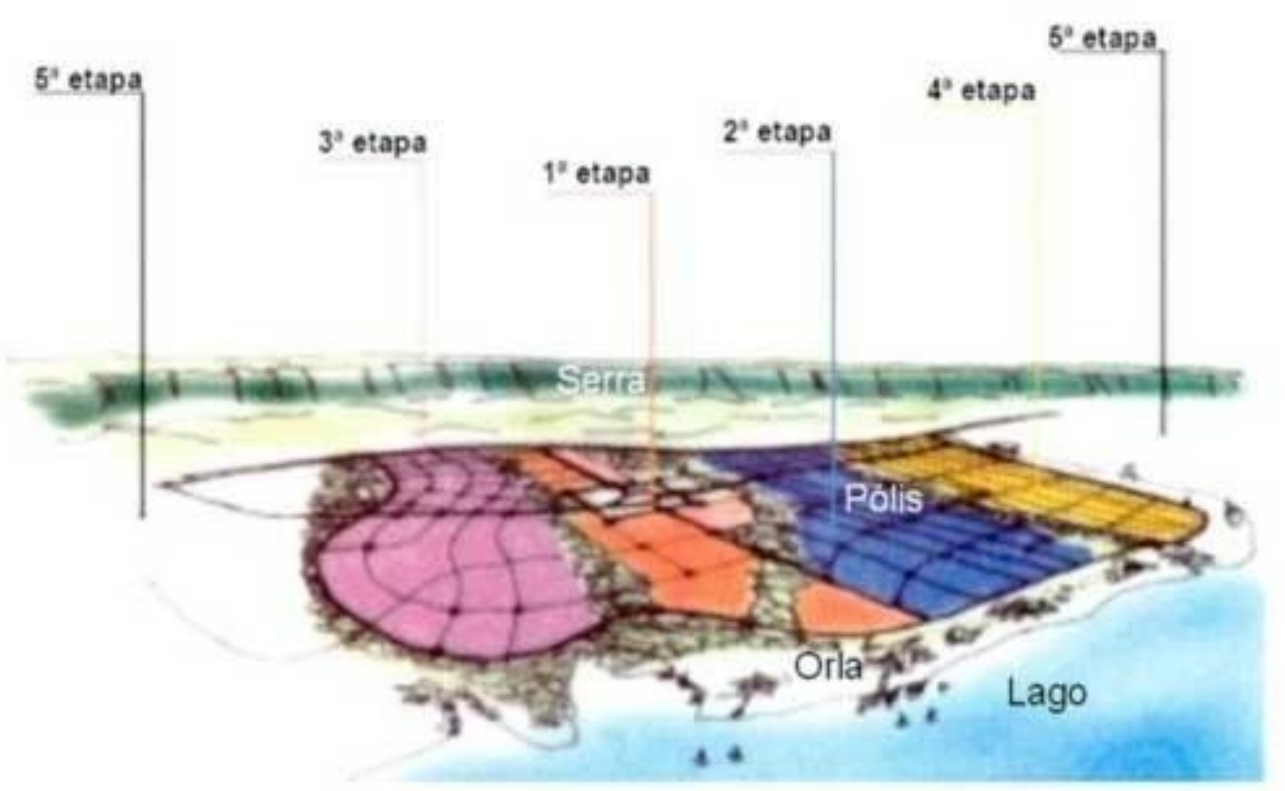

Figura 02 - Proposta de ocupação sequenciada de Palmas [Caderno de Revisão do Plano Diretor de Palmas. Palmas, 2005]

Cada etapa seria ocupada quando a anterior já estivesse suficientemente adensada. Entretanto, essa ocupação planejada foi desrespeitada pelo próprio governo estadual. Não houve o adensamento populacional conforme a sequência prevista.

Já na fase inicial de Palmas observou-se um processo de ocupação desordenada decorrente da questão imobiliária. Conforme explica Teixeira (2009), "com o avanço da urbanização, o Estado desapropriava terra rural e vendia terra urbana já valorizada pela ação governamental”. Em janeiro de 1990, já fora iniciada a venda dos lotes por leilão público impulsionando as primeiras veias de um mercado imobiliário perverso e excludente que tão logo se estabeleceria na cidade.

Áreas, como a expansão norte e sul, pertencentes a quinta etapa, que deveriam 
ser ocupadas somente após a urbanização de $70 \%$ da área projetada, foram logo ocupadas, embora desprovidas de infraestrutura básica. Essa situação de exclusão é explicitada por Teixeira em entrevista a Segawa (1991).

O governo resolveu abrir frentes de ocupação de maneira diferente daquela planejada, doando lotes em áreas afastadas da parte central da cidade para migrantes. Na realidade, o governo fez uma distinção entre pessoas de maior e menor poder aquisitivo. [...]. O governo deu terreno de graça para a população pobre: criou, a cerca de $20 \mathrm{Km}$ de Palmas, próxima a uma localidade chamado Taquaralto - não era mais que um aglomerado de casas, a vila Aureny; depois a Vila Aureny II, III [...]. Por várias experiências passadas, isso é uma equação conhecida: não basta fazer uma ação filantrópica, dando terreno ou material de construção. Essa população precisa ter o se chama de "inserção urbana": precisa ter terreno, mas também emprego, renda para pagar água encanada, energia elétrica, etc.

Rodovalho (2012 apud Bazolli, 2012) salienta que o próprio governo estadual deturpou o mecanismo de venda de terras para implantação de infraestrutura da cidade ao adotar "políticas de doação de áreas, glebas e lotes com o uso da terra como mercadoria política e em favor do mercado imobiliário".

Os resultados da inversão do planejamento quanto à ocupação do plano básico são facilmente percebidos na figura abaixo. É evidente a concentração de grandes núcleos populacionais afastados da cidade planejada:
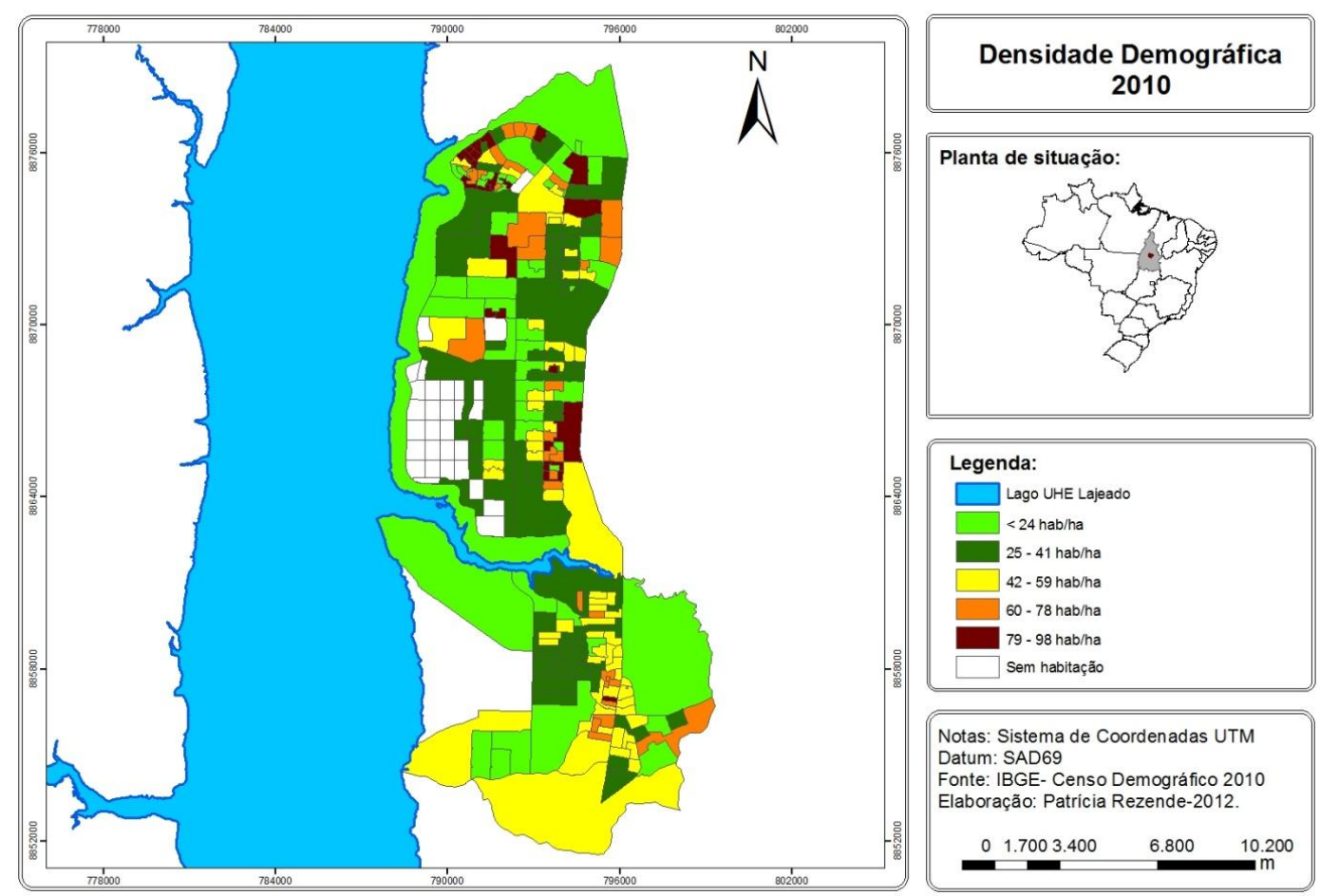

Figura 02- Mapa de Densidade populacional da cidade de Palmas - TO [Cadastro Técnico Multifinalitário, Palmas, 2004] 
Nas palavras de Teixeira (2009), “... uma cidade, antes de ser um produto acabado, é um processo sem fim". Os planejadores buscaram desenvolver um plano a fim de definir questões e regras básicas de organização do espaço urbano capazes de orientar a implantação da cidade ao longo do tempo. Entretanto, "o processo de gestão e implantação da cidade por parte do governo foi orientado principalmente por questões políticas em detrimento das orientações do plano diretor".

Como se percebe, Palmas, já no início de sua formação, apresentou questões que se tornaram e continuarão a ser grandes problemas sociais. A primeira grande problemática diz respeito ao custo de urbanização da cidade, pois na medida em que a população carente é impulsionada para ocupar áreas distantes, surge para o governo a obrigação de colocar infraestrutura em várias direções da cidade, porém não se tem condições para arcar com todas elas. Outra questão a ser levantada, é a favelização dos arredores da cidade como consequência do abandono do poder público, bem como do levantamento de construções precárias e irregulares. E por fim, a problemática mais evidente, certamente a causadora de todas as demais, diz respeito à forte e intensa especulação imobiliária, iniciada pelo governo e continuada pela iniciativa privada, caracterizada pela retenção do núcleo central da cidade no domínio do governo e da classe dominante.

\subsection{O Plano Diretor participativo do município de Palmas e o princípio da gestão democrática da cidade}

Em dezembro de 2007 foi instituído, pela Lei Complementar no 155/07, o Plano Diretor Participativo do Município de Palmas/TO. Essa lei busca efetivar a determinação constitucional instituída no art.182 da CRFB/88, segundo o qual a política de desenvolvimento urbano executada pelos municípios objetivará ordenar o pleno desenvolvimento das funções sociais da cidade e da propriedade.

Baseada nessa determinação constitucional, a LC 155/07 instituiu, como princípios do Plano Diretor de Palmas, a função social da cidade e da propriedade; a inclusão social; a humanização da cidade; a proteção do meio ambiente e de seus bens comuns e vitais ao homem e; a sustentabilidade e equidade social, econômica e ambiental.

Coriolano, Oliveira e Rodrigues (2013) ressaltam que, durante a realização do diagnóstico do Plano Diretor, foi identificado que a segregação socioterritorial na cidade é um dos principais problemas urbanísticos. Como decorrência, a Lei do Plano Diretor 
estabeleceu importantes objetivos que buscam, de alguma forma, reduzir as desigualdades e promover o acesso à terra urbanizada. Esses objetivos são claramente identificados no art. 12 da Lei Complementar 155/07:

\footnotetext{
Art. 12. São objetivos do Plano Diretor de Palmas:

[...]

II - democratizar o acesso a terra, à moradia e aos serviços públicos de qualidade, revertendo o processo de segregação socioespacial;

$\mathrm{V}$ - coibir o uso especulativo do imóvel urbano de modo a assegurar o cumprimento da função social da propriedade;

VII - intensificar o uso e ocupação dos lotes nas áreas com infraestrutura e equipamentos instalados;

$\mathrm{VI}$ - a democratização do planejamento e da gestão territorial (Grifo nosso)
}

O processo de discussão e elaboração do Plano Diretor de Palmas contemplou a aplicação do princípio da gestão democrática. Segundo Bazolli (2012), "a LC n ¹55/07 foi construída durante o período de um ano e meio priorizando a participação da sociedade em todas as etapas de elaboração". Até o momento de promulgação da lei, o projeto já havia percorrido importantes etapas buscando ao máximo a participação popular através de reuniões, fóruns, audiências, seminários temáticos, etc.

A LC № 155/07 institui um título específico para tratar da gestão democrática da cidade estabelecendo objetivos e instrumentos para garantir a participação da população nos programas e projetos urbanísticos de Palmas. No art. 106 foram elencados os instrumentos da gestão democrática, dentre os quais, os conselhos municipais e as audiências e consultas públicas. Ficou estabelecido ainda, no art. 109, que ao Conselho de Desenvolvimento Urbano e Habitação compete, dentre outras atribuições, o monitoramento do Plano Diretor e da legislação urbanística complementar, bem como a avaliação dos relatórios e dos pareceres técnicos de alienação de áreas públicas municipais.

O princípio da gestão democrática da cidade parece estar plenamente contemplado no Plano Diretor de Palmas sendo perseguido desde sua elaboração. Entretanto, ainda é longo o caminho a ser percorrido para que de fato aconteça a efetiva participação da população palmense nas decisões do futuro da cidade.

\section{ALTERAÇÕES DO PLANO DIRETOR DE PALMAS NOS ANOS DE 2011 E 2012}

Nos anos de 2011 e 2012 , a LC 155/07 foi alvo de importantes discussões e até mesmo de significativas alterações. Nesse período foram discutidos quatro projetos de 
para alteração do Plano Diretor de Palmas. Dentre estes, o PLC 12 que foi sorrateiramente aprovado e originou a LC 253/12. Os demais, PLCs № 06, 07 e13, tiveram o respectivo trâmite suspenso em decorrência de irregularidades do processo legislativo e, sobretudo, em razão das intensas manifestações contrárias por parte de importantes segmentos da sociedade palmense.

\subsection{Projetos de Lei Complementar № 06 E 07}

Em 22 de junho de 2011, o então prefeito de Palmas, Raul Filho, encaminhou mensagem à Câmara Municipal de Vereadores submetendo, para discussão e aprovação, - Projeto de Lei Complementar no 06/11 que alterava e acrescia artigos à Lei Complementar no 155/07 - Plano-Diretor de Palmas.

As alterações propostas pelo PLC nำ06/11 estabeleciam nova redação para os artigos 14, 15 e 18, e acrescia o art. 17-A à LC no 155/07. O quadro abaixo faz um comparativo das alterações pretendidas:

\begin{tabular}{|c|c|}
\hline Redação original dos artigos na LC no $155 / 07$ & Redação proposta para alteração \\
\hline $\begin{array}{l}\text { TíTULO IV } \\
\text { Do Ordenamento Territorial } \\
\text { CAPÍTULO I } \\
\text { Do Macrozoneamento } \\
\text { Art. 14. O município de Palmas fica dividido em } \\
\text { áreas urbanas, área de urbanização específica, } \\
\text { área de urbanização de interesse turístico e rural } \\
\text { por meio da delimitação do perímetro urbano, } \\
\text { conforme mapa no. 01, modificado constante do } \\
\text { anexo I desta Lei e do Memorial Descritivo, } \\
\text { modificado nos arts. 15, 16 e } 17 \text { desta Lei }\end{array}$ & $\begin{array}{l}\text { Art. 14. O município de Palmas fica dividido em } \\
\text { áreas urbanas, área de urbanização específica, } \\
\text { área de urbanização de interesse turístico e } \\
\text { área rural por meio da delimitação do perímetro } \\
\text { urbano. } \\
\text { \$1ํ- A delimitação do perímetro e a divisão das } \\
\text { áreas urbanas e rurais ficam definidas conforme } \\
\text { mapa no. } 01 \text {, constante do Anexo Único desta } \\
\text { Lei. } \\
2^{\circ} \text { As áreas de urbanização específica e as } \\
\text { áreas de interesse turístico serão criadas } \\
\text { através de leis próprias, e terão como base a } \\
\text { vocação natural do solo, a vegetação existente } \\
\text { e o potencial socioeconômico da região em } \\
\text { relacão aos usos pretendidos. }\end{array}$ \\
\hline $\begin{array}{l}\text { Seção I } \\
\text { Do Perímetro Urbano } \\
\text { Art. 15. O perímetro Urbano de Palmas é a linha } \\
\text { que delimita por Lei as áreas urbanas, área de } \\
\text { urbanização específica, área de urbanização de } \\
\text { interesse turístico separando-as da área rural. } \\
\text { §1 As áreas urbanas de loteamentos isolados são } \\
\text { delimitadas pelo perímetro dos loteamentos } \\
\text { aprovados, conforme suas plantas de aprovação e } \\
\text { memoriais descritivos. }\end{array}$ & $\begin{array}{l}\text { Art. 15................................................... } \\
3^{\circ} \text { As áreas de urbanizaçáo especicas e as } \\
\text { áreas de urbanização de interesse turísticos } \\
\text { serão delimitadas por leis próprias. }\end{array}$ \\
\hline $\begin{array}{l}\text { Seção III } \\
\text { Da Área de Urbanização Específica } \\
\text { Art. 17. VE T A D O }\end{array}$ & $\begin{array}{l}\text { 17-A As áreas de urbanização específica serão } \\
\text { reservadas a parcelamento do solo para usos } \\
\text { diferenciados daqueles previstos nas Leis de } \\
\text { Uso e Ocupação do Solo, destinado a grandes } \\
\text { equipamentos e a Zonas Especiais de Interesse }\end{array}$ \\
\hline
\end{tabular}




\begin{tabular}{|c|c|}
\hline & $\begin{array}{l}\text { Social - ZEIS. } \\
\text { Parágrafo Único. Nas Áreas de Urbanização } \\
\text { Específicas é vedado o micro parcelamento e } \\
\text { a instituição de condomínios e similares para } \\
\text { fins de moradia exceto para implantação de } \\
\text { Zonas Especiais de Interesse Social - ZEIS. }\end{array}$ \\
\hline $\begin{array}{l}\text { Seção IV } \\
\text { Da Área Rural } \\
\text { Art. 18. Toda área inserida nos limites do } \\
\text { município, que esteja localizada fora do perímetro } \\
\text { urbano das áreas urbanas isoladas e da área de } \\
\text { urbanização específicas, área de urbanização de } \\
\text { interesse turístico é considerada rural. } \\
\S 1^{\circ} \text { Cabe ao município estabelecer diretrizes de } \\
\text { integração e a complementaridade das atividades } \\
\text { rurais e urbanas, tendo em vista o seu } \\
\text { desenvolvimento socioeconômico e do território } \\
\text { sob sua área de influência, desde que verificada } \\
\text { compatibilidade no Zoneamento Ambiental, de } \\
\text { forma Ecológico-Econômica - ZEE, conforme Lei no } \\
\text { 1.011/2001 e as disposições legais, Federal e } \\
\text { Estadual. }\end{array}$ & 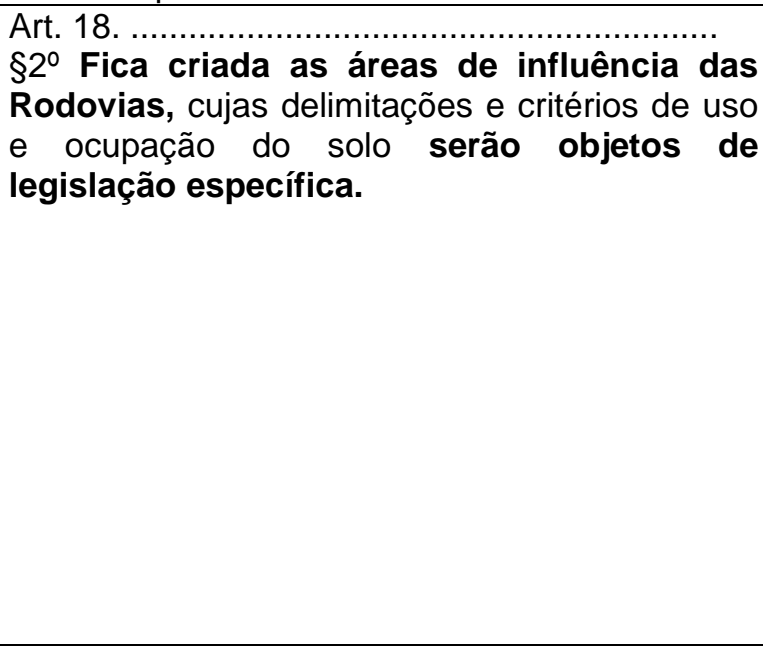 \\
\hline $\begin{array}{l}\text { Art. 23. O Perímetro Urbano da Sede do Município } \\
\text { de Palmas fica dividido pelas seguintes áreas } \\
\text { estruturantes: } \\
\text { X - Área de Urbanização Específica - Localizada } \\
\text { na área de influência das rodovias, descrita no } \\
\text { Art. } 17 \text { desta Lei, será destinada a equipamentos } \\
\text { de maior porte, com reduzido impacto ambiental, } \\
\text { uso misto de média densidade, permitindo a } \\
\text { implantação de condomínios industriais, } \\
\text { tecnológicos, comerciais, de serviços e } \\
\text { residenciais fechados, postos de abastecimento de } \\
\text { combustíveis, hotéis, motéis, promovendo o } \\
\text { adensamento próximo aos eixos estruturantes, } \\
\text { bem como exploração agrícola, pecuária, extrativo- } \\
\text { vegetal, florestal ou agroindustrial, com os mesmos } \\
\text { usos e ocupações das áreas urbanas equivalentes. }\end{array}$ & $\begin{array}{l}\text { Art. 23. O Perímetro Urbano da Sede do } \\
\text { Município de Palmas fica dividido pelas } \\
\text { seguintes áreas estruturantes: } \\
\text { X-Revogado }\end{array}$ \\
\hline
\end{tabular}

O Executivo Municipal apresentou como justificativa para as alterações: que o Plano Diretor, segundo o Estatuto da Cidade, deverá englobar o território do município como um todo. Portanto o Plano Diretor de Palmas deveria abranger tanto a zona urbana como a zona rural.

Concomitantemente, fora encaminhando, também, o Projeto de Lei Complementar no 07 que visava à regulamentação da Área de Influência das Rodovias, mantendo essas áreas como zona rural. Quanto a essas áreas, o Prefeito usou como justificativa a necessidade de promoção do adensamento próximo aos eixos estruturantes previstos na LC № 155/07, pois as áreas de influência das rodovias teriam destinação a equipamentos de maior porte, com reduzido impacto ambiental, uso misto de média densidade, com os mesmos usos e ocupações das áreas urbanas equivalentes. 
Observamos que na proposta de alteração, o Executivo Municipal buscava regulamentar, com a criação do art. 17-A, as áreas de urbanização específica, assunto até então vetado na LC no 155/07. Mais adiante, na seção que trata da área rural, o Prefeito criava as áreas de influência das rodovias (art. 18, $\S 2^{\circ}$ ). Com o PLC $\mathrm{n}^{\circ} 07$ buscou-se regulamentar o uso das áreas de influência das rodovias, especificando a implantação de empreendimentos nessas áreas.

Os PLCs no 06 e 07 foram encaminhados à Câmara Municipal apresentando anexos apenas um mapa e a justificativa do Executivo Municipal. Não houve nenhum estudo complementar a fim de definir as razões técnicas e o modo de como se daria a integração entre as zonas rural e urbana na área de influência das rodovias.

Na LC no 155/07, Lei do Plano Diretor de Palmas, há previsão de revisão do plano, estabelecendo os devidos parâmetros como o levantamento da necessidade de áreas para ocupação, análise da taxa de crescimento da população urbana, bem como a apresentação de estudos técnicos prévios necessários e devidamente avaliados pelo Sistema Municipal de Acompanhamento e Controle (SMAC), órgão competente para coordenar a implementação do Plano Diretor e os processos de sua revisão e atualização (BAZOLLI, 2012).

Durante a tramitação dos PLCs no 06 e 07 foi editada, pelo Governo Federal, em outubro de 2011, a Medida Provisória no 547/11 que acrescentava o art. 42-A ao Estatuto da Cidade. Essa MP estabelecia aos municípios a obrigatoriedade do cumprimento de requisitos mínimos para alteração de seu respectivo perímetro urbano. Segundo a redação do novo art. 42-A, os municípios que possuíssem áreas de expansão urbana deveriam elaborar o Plano de Expansão Urbana no qual deveria constar, dentre outros elementos, a demarcação da área de expansão.

Em abril do ano 2012 a MP 547/11 foi convertida na lei federal 12.608/12 a qual dispõe em seu art. 26 que a Lei $n-10.257$, Estatuto da Cidade, passa a vigorar acrescida dos arts. 42-A e 42-B. No tocante a ampliação do plano diretor, assim dispõe o atual art. 42-B da lei 10.257/11:

Art. 42-B. Os Municípios que pretendam ampliar o seu perímetro urbano após a data de publicação desta Lei deverão elaborar projeto específico que contenha, no mínimo:

I - demarcação do novo perímetro urbano;

II - delimitação dos trechos com restrições à urbanização e dos trechos sujeitos a controle especial em função de ameaça de desastres naturais;

III - definição de diretrizes específicas e de áreas que serão utilizadas para infraestrutura, sistema viário, equipamentos e instalações públicas, urbanas e sociais; 
IV - definição de parâmetros de parcelamento, uso e ocupação do solo, de modo a promover a diversidade de usos e contribuir para a geração de emprego e renda;

$\mathrm{V}$ - a previsão de áreas para habitação de interesse social por meio da demarcação de zonas especiais de interesse social e de outros instrumentos de política urbana, quando o uso habitacional for permitido;

VI - definição de diretrizes e instrumentos específicos para proteção ambiental e do patrimônio histórico e cultural; e

VII - definição de mecanismos para garantir a justa distribuição dos ônus e benefícios decorrentes do processo de urbanização do território de expansão urbana e a recuperação para a coletividade da valorização imobiliária resultante da ação do poder público.

Por essa disposição legal restou evidente que os municípios que pretendem expandir o perímetro urbano de seus respectivos planos diretores ficam obrigados a realizar um plano de expansão respaldado por documentos e estudos técnicos necessários e justificadores da necessidade de expansão.

A apresentação do PLC № 06 à Câmara Municipal antes da edição da MP 547/11 e sua respectiva conversão na Lei 12.608/12 não the garante por si só a legalidade devida. Se eventualmente o PLC no 06 viesse a ser aprovado, teríamos uma lei estadual eivada de vício de legalidade ante uma lei federal, qual seja, o Estatuto da Cidade previsto constitucionalmente no art. 182 como lei de caráter geral apta a regular as diretrizes gerais a partir das quais os municípios devem executar suas respectivas políticas de desenvolvimento urbano. Entretanto, apesar da promulgação da Lei 12.608/12, os PLCs no 06 e 07 continuaram a tramitar no Legislativo.

O PLC no 06 ainda incorreu na desconsideração dos apontamentos levantados pelo Conselho de Desenvolvimento Urbano e Habitação de Palmas, órgão criado pela Lei $1.384 / 05$ e competente para, dentre outras atribuições, propor a edição de normas gerais de direito urbanístico e manifestar-se sobre propostas de alteração da legislação municipal pertinente.

Em junho de 2011, segundo Bazolli (2011), a matéria concernente ao PLC o 06 foi apresentada ao Conselho de Desenvolvimento Urbano e Habitação de Palmas (CDUHP) que deliberou, por unanimidade, que fossem realizadas, pelo Executivo Munipal, audiências públicas a fim de discutir acerca da Área de Influência das Rodovias. Durante as discussões no CDUHP, merecem destaque os seguintes apontamentos:

O conselheiro César Augustus de S. Amaral ao iniciar a discussão do tema frisa claramente "a reunião não é para tratar da ampliação do perímetro urbano de Palmas e sim tratar da área de influência das rodovias que se encontra no Plano Diretor como área rural, tendo como finalidade promover o adequado desenvolvimento da região tanto economicamente como socialmente."

O conselheiro representante da Câmara Bismarque Roberto adverte os conselheiros

"a pressão que os vereadores da Câmara estão sofrendo por parte dos 
empresários para que se possa alterar a minuta de lei que trata da área de influência das rodovias no entorno de Palmas, o qual os mesmos querem que se destine esta área não para a construção de grandes equipamentos e sim para a abertura de grandes condominios e loteamento. " conclue a sua fala " os vereadores já estão com outra minuta de lei pronta da que será proposta pela SEDUH, para que se possa aprovar a construção de condominios fechados e lotementos na área." O técnico da (CAIXA) André relatou "que já foi dada entrada na instituição um empreendimento com 800 apartamentos, na Área de Influência das Rodovias e que o empresário disse que estava tudo certo com a Prefeitura e Câmara, que tudo estaria aprovado até agosto." (Grifos do autor)

Da análise das discussões levantadas nessa reunião, percebe-se uma preocupação por parte do CDUHP de que as áreas de influência das rodovias, até então consideradas área rural, tornem-se, na verdade, áreas de expansão do perímetro urbano sob o pretexto de regulamentação do uso dessas áreas como se fossem áreas de urbanização específica, podendo vir a serem usadas inclusive para edificação de condomínios fechados.

Ademais, as recomendações quanto à realização das audiências públicas não foram seguidas pelo Executivo. Desse modo, os PLCs ํํ 06 e 07 foram enviados à Câmara Municipal para que ela mesma realizasse as audiências públicas e posteriormente discutisse e aprovasse os projetos de lei. Posteriormente, ao ser convocado pela Câmara Municipal cujo intuito era validar a remessa dos PLCs feita pelo Executivo, o Conselho de Desenvolvimento Urbano e Habitação de Palmas se manteve firme no posicionamento de que os PLCs deveriam ser remetidos àquela Casa somente após a realização das audiências públicas pelo Executivo. Essa postura do CDUHP se consubstanciou, segundo Bazolli (2011), no receio do Conselho de que, naquele momento, as discussões se convergissem "única e exclusivamente para a expansão urbana da cidade".

É exatamente nesse ponto que toda a discussão toma corpo, ganhando destaque na mídia local e nos espaços públicos de discussão, como na Universidade Federal do Tocantins/UFT e no Conselho de Arquitetura e Urbanismo do Tocantins/CAU-TO, passando pelo Ministério Público Estadual e chegando até o Tribunal de Justiça do Estado.

\subsection{Emenda Substitutiva 001/12}

Apesar da discussão acerca dos PLCs no 06 e 07, inicialmente, não se tratar da ampliação do perímetro urbano da cidade, os debates tomaram esse rumo. A questão da 
expansão urbana de Palmas passou a ser tema de debates no rádio, na televisão e também na universidade.

A questão da expansão do perímetro urbano da cidade retoma a discussão acerca dos problemas de ocupação do espaço urbano desde a fundação de Palmas. A história da cidade é marcada pelo descumprimento, por parte do governo estadual, do plano urbanístico básico com a deliberada intenção de promover a retenção de imóveis do plano diretor para fins especulativos, uma vez que o governo desapropriava terra rural e a valorizava por meio da instalação de equipamentos urbanos para depois vendê-la. Essa prática foi seguida por grupos do setor imobiliário, bem como por empreiteiras que receberam terras como dação em pagamento por cumprimento de contratos com o governo.

Ademais, não se pode esquecer da política de segregação social configurada pelas doações de lotes pelo governo à população de baixa renda, de modo a não restar-lhe outra opção senão ocupar aqueles espaços, até então sem infraestrutura mínima para habitação. Essa forma de implementação da cidade desencadeou uma série de problemas de ordem urbanística como as invasões, os vazios urbanos, o aumento do custo de urbanização e, o pior de todos, a continuidade da segregação social.

Interessado na possibilidade de expansão da cidade, o Conselho Regional de Corretores de Imóveis do Estado do Tocantins - CRECI/TO, em janeiro de 2012, dirigiu o ofício no 001/2012 cujo assunto foi: “A Expansão da Área Urbana de Palmas”. Nesse documento, o CRECI buscou circunstanciar a necessidade de que a Câmara Municipal considerasse, dentre outros fatores, que era necessário atrair investimentos imobiliários para a "nossa capital"; que o programa Minha Casa Minha Vida dependia da disponibilização de terrenos a preços razoáveis; que a ampliação da área urbana ou de expansão urbana será fator de equilíbrio entre a oferta e a demanda, oportunizando preços razoáveis para os terrenos na capital; etc.

O ofício em questão se encerra com a com a seguinte sugestão do $\mathrm{CRECl}$ à Câmara Municipal:

SUGERE ao Legislativo Municipal a aprovação de alterações no Plano Diretor de Palmas nos termos a seguir:

Ampliação da área urbana ou de expansão urbana de Palmas para fins de loteamento nos seguintes limites:

a) $15 \mathrm{Km}$ ao norte e ao sul - tendo como ponto de partida o final do plano diretor em cada extremo - e de oeste a leste abrangendo toda a extensão que vai do Lago da Usina do Lajeado (cota 212) ate os limites da Serra do Carmo. 
Da análise deste documento, resta evidente o forte interesse do setor imobiliário na aprovação da expansão do perímetro urbano. Utilizando-se de um discurso progressista, o ramo imobiliário procura justificar seus interesses tentando sustentar a ideia de que expansão traria o acesso à terra através de investimentos imobiliários privados. Porém, na realidade, o que a expansão do perímetro urbano de imediato propicia é a produção capitalista do espaço através da elevação do solo à condição máxima de mercadoria (SIQUEIRA; VILARINHO NETO, 2012).

Desconsiderando a MP 547/11, a Câmara Municipal, ainda em janeiro de 2012, propõe ao PLC no 06 a Emenda Substitutiva no 001/2012 cujo texto prevê a ampliação do perímetro urbano, diferentemente da proposta original do projeto encaminhado que apenas criava a área de influência das rodovias, porém mantendo-a na zona rural, de modo que o perímetro urbano permaneceria inalterado.

O texto final da ES 001/2012 é resultante de uma série de emendas propostas por diferentes vereadores da Câmara. O primeiro a propor uma emenda ao projeto do Executivo foi o Vereador Milton Neris, à época Líder de Governo e, em sintonia com o Executivo. Dentre suas propostas de alteração cabe ressaltar a volta do inciso $X$ do art. 23, a modificação do art. 17-A e a alteração da redação dos art.s 19 e 43 até então não mencionados no respectivo PLC. Abaixo, faz-se um comparativo entre as proposições do

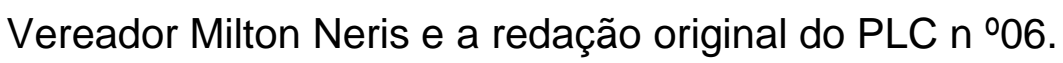

Quanto aos art. 17-A e 23:

Proposta do PLC $\cong 06$ formulada pelo Executivo:

Art. 17-A As áreas de urbanização específica serão reservadas a parcelamento do solo para usos diferenciados daqueles previstos nas Leis de Uso e Ocupação do Solo, destinado a grandes equipamentos e a Zonas Especiais de Interesse Social - ZEIS.

Parágrafo Único. Nas Áreas de Urbanização Específicas é vedado o micro parcelamento e a instituição de condomínios e similares para fins de moradia exceto para implantação de Zonas Especiais de Interesse Social - ZEIS (Grifo nosso)

Proposta do Líder de Governo:

Art. 17-A As áreas de urbanização específica delimita-se como a área de influência das rodovias a faixa de terra ao longo das Rodovias TO-010 e TO-050, com projeção horizontal de até 700,00 (setecentos metros) a partir da faixa de domínio do DERTINS até o Ribeirão Taquaruçu Grande.

Art. 23

$X$ - Área de Urbanização Específica - Localizada na área de influência das rodovias, descrita no Art. 17-A desta Lei, será destinada a equipamentos de maior porte, com reduzido impacto ambiental, uso misto de média densidade, permitindo a implantação de condomínios industriais, tecnológicos, comerciais, de 
serviços e residenciais fechados, postos de abastecimento de combustíveis, hotéis, motéis, promovendo o adensamento próximo aos eixos estruturantes, bem como exploração agrícola, pecuária, extrativo-vegetal, florestal ou agroindustrial, com os mesmos usos e ocupações das áreas urbanas equivalentes. (Grifo nosso)

Na proposta do Vereador Milton Neris, o inciso X do art. 23 da LC155/07 retoma ao texto legal sendo conjugado com o novo art. 17-A estabelecendo que a Área de Urbanização Específica estará localizada na área de influência das Rodovias numa faixa de 700,00m ao longo da TO-010 e da TO-050. Ainda segundo essa proposta, nessa área poderão ser instalados uma vasta gama de equipamentos de urbanização como condomínios industriais, comerciais, hotéis, motéis e sobretudo residenciais fechados.

Saltam incoerências quando da comparação entre as propostas do Executivo com as do Líder de Governo. A priori, na proposta do PLC № 06, o Prefeito criava dentro da área rural, através da inserção do $\S 2^{\circ}$ ao art. 18 da LC № 155/07, a área de influência das rodovias sem defini-las especificamente. $E$ também revogava o inciso $X$ do art. 23 de modo a impedir legalmente que as áreas de influências das rodovias fizessem parte do perímetro urbano. Contrariamente a essa proposta, a emenda do Vereador Milton Neris amplia o perímetro urbano transformando as áreas de influências das rodovias em áreas urbanas denominando-as de Áreas de Urbanização Específica.

Outra grande diferença refere-se ao uso das Áreas de Urbanização Específicas em cuja proposta do Executivo, ficaria vedado o micro parcelamento e a instituição de condomínios e similares para fins de moradia exceto para implantação de Zonas Especiais de Interesse Social. Diferentemente, na proposta do Líder de Governo, o uso dessas áreas teria os mais variados fins inclusive a formação de loteamentos, bem como a implantação de condomínios fechados.

O Líder de Governo vai além e propõe também alterações significativas nos artigos 19 e 43 da LC ํํ 155/07 que até então nem sequer constavam do PLC $n \cong 06$.

No quadro abaixo se faz um comparativo da redação original dos referidos artigos em relação à proposta do Vereador Milton Neris. 


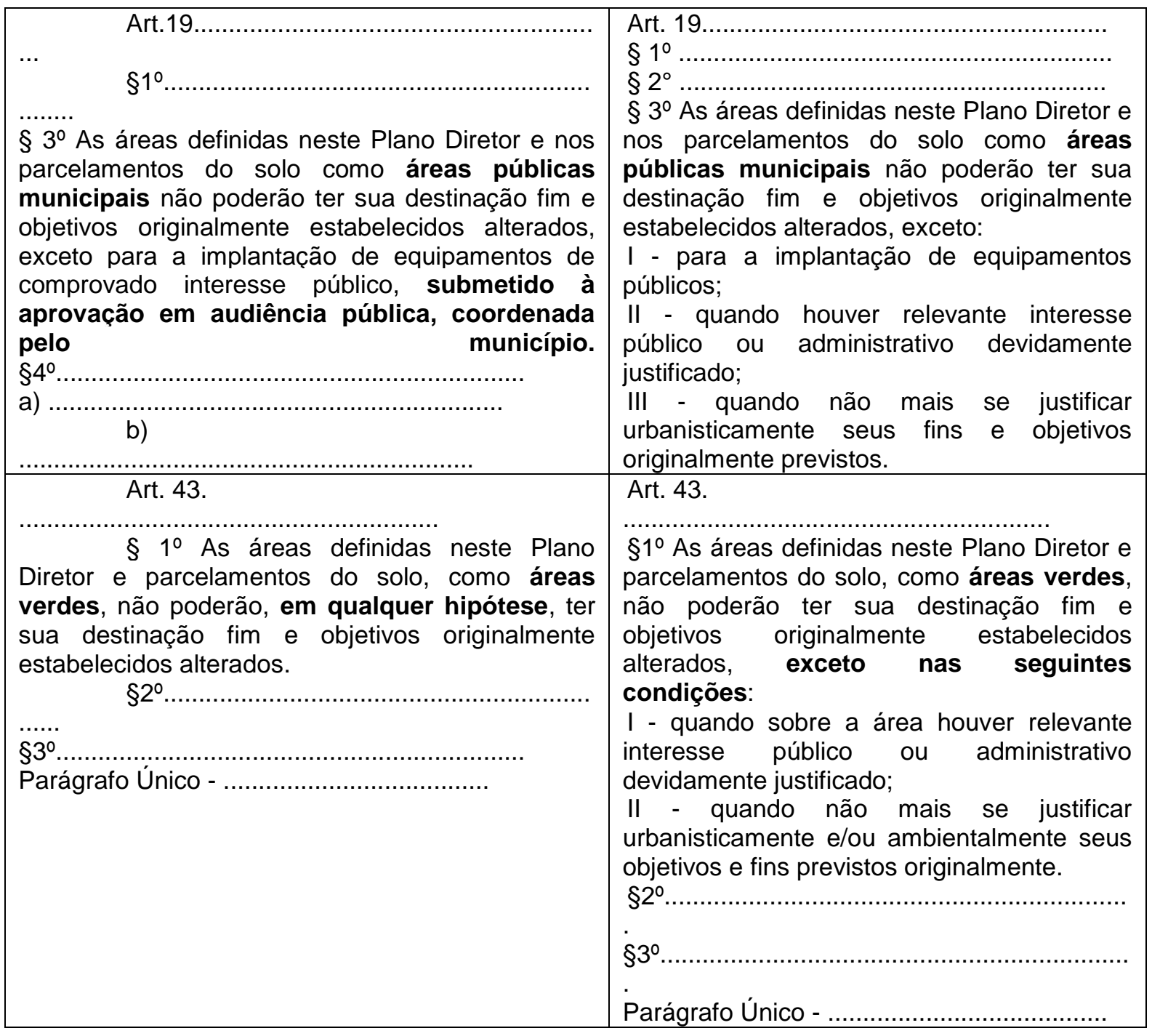

As Áreas Públicas Municipais - APM, destinadas à implantação de equipamentos urbanos e comunitários, são bens públicos de uso comum do povo e de uso especial, ou seja, essas áreas são bens com destinação específica, podendo ser utilizadas por todos em igualdade de condições ou pela Administração Pública para o fornecimento de serviços públicos e/ou para o estabelecimento de seus órgãos. Enquanto conservarem essa qualificação, as APM são inalienáveis, conforme preceitua o art. 100 do Código Civil de 2002.

Entretanto, da análise da proposta de alterações à LC nำ155/07, no que tange às Áreas Públicas Municipais, infere-se que o Vereador Milton Neris busca retirar a legitimidade das audiências públicas para aprovar a alteração da destinação fim das APM, estabelecendo um rol bastante subjetivo de excepcionalidades em que o Poder Executivo e o Legislativo possam sozinhos, sem consultar a comunidade, desafetar essas áreas.

Um ponto ainda mais preocupante dessa proposta diz respeito às Áreas Verdes 
destinadas, segundo o art. 43 da LC 155/07, à implantação ou preservação de arborização, ajardinamento, lazer e recreação. São áreas que buscam assegurar boas condições ambientais à população, além de proporcionar o contato da população com a natureza. Na redação original, a destinação fim e os objetivos das Áreas Verdes não poderiam ser alterados em quaisquer que fossem as hipóteses. Desse modo, o legislador buscou dar máxima proteção à finalidade a que se destinavam essas áreas, não permitindo de maneira alguma que a população fosse privada da existência delas.

Todavia, pela proposta de alteração do vereador Milton Neris, a destinação dessas áreas poderá ser facilmente alterada pelo Executivo, não exigindo sequer a realização de audiência pública para consultar a opinião da comunidade a ser afetada. As condições propostas para justificar a alteração da destinação fim das Áreas Verdes são impregnadas de subjetividades, fundando-se em conceitos abertos como "relevante interesse público ou administrativo", que geralmente dependem apenas da mera discricionariedade do gestor.

A proposta da Câmara Municipal veiculada pela ES 001/2012 denotou a clara intenção do corpo Legislativo em expandir o perímetro urbano de Palmas desvirtuando por completo o projeto do Executivo Municipal que tão somente previa a criação e regulamentação da área de influência das rodovias na zona rural.

O mapa abaixo elaborado por Patrícia Rezende (2012) demonstra as faixas de expansão pretendidas pela ES 001/2012: 

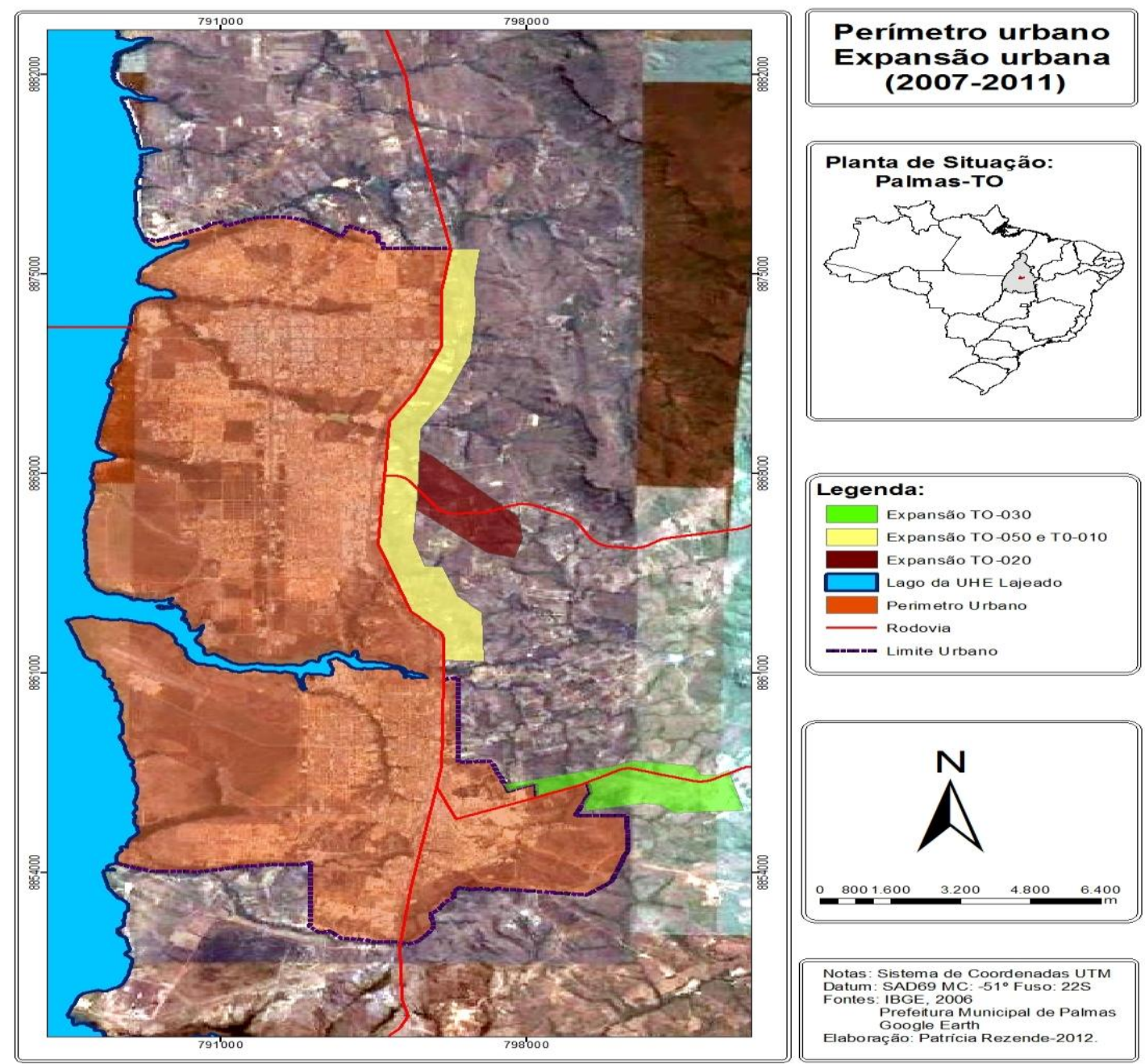

Figura 03: Mapa de expansão do perímetro urbano de Palmas/TO

\subsection{Manifestações contrárias Aos PLCs № 06 E 07}

A postura do Legislativo Municipal intensificou a discussão sobre a questão urbana de Palmas provocando a reprovação pelo Conselho de Desenvolvimento Urbano e Habitação que se posicionou em desacordo com a ES 001/2012 do Legislativo e editou, em março de 2012, a Resolução 008/2012 sugerindo ao Prefeito Municipal a retirada da respectiva emenda. Assim dispõe o art. 1ำ da Resolução 008/2012:

Art. $1^{\circ}$ recomenda o Prefeito Municipal de Palmas pela manutenção do Projeto de Lei no 006/2011, de 22 de junho de 2011 e a retirada da Emenda Substitutiva no 001/2012. (Grifo nosso)

O Conselho Municipal de Desenvolvimento Urbano e Habitação de Palmas é o órgão colegiado de política urbana em nível municipal previsto no art. 43, inciso I do Estatuto da Cidade como instrumento usado para garantir a gestão democrática da 
cidade. Dentre as competências do CDUHP, consta a de coordenar o processo participativo de elaboração do Plano Diretor em todas as etapas conforme determina a Resolução no 25 do Conselho das Cidades, órgão instituído em nível nacional para emitir resoluções sobre a aplicação da Lei 10.257/01:

Art. 3ㅇ O processo de elaboração, implementação e execução do Plano diretor deve ser participativo, nos termos do art. $40, \S 4^{\circ}$ e do art. 43 do Estatuto da Cidade.

$\S 1^{\circ}$ A coordenação do processo participativo de elaboração do Plano Diretor deve ser compartilhada, por meio da efetiva participação de poder público e da sociedade civil, em todas as etapas do processo, desde a elaboração até a definição dos mecanismos para a tomada de decisões.

$\S 2^{\circ}$ Nas cidades onde houver Conselho das Cidades ou similar que atenda os requisitos da Resolução № 13 do CONCIDADES, a coordenação de que trata o §1, poderá ser assumida por esse colegiado; (Grifo nosso)

Cabe ressaltar que a gestão democrática da cidade é uma das diretrizes gerais fixadas pelo Estatuto da Cidade e decorre dos princípios da política urbana instituída no art. 182 da CRFB/88. Desse modo, a gestão democrática vincula as ações municipais na execução da política de desenvolvimento urbano. Portanto, a postura tanto do Executivo quanto do Legislativo Municipal desrespeitam a legislação infraconstitucional ao não contemplar, em suas decisões, a participação do Conselho de Desenvolvimento Urbano e Habitação de Palmas que possui competência legal para propor debates acerca das questões urbanas a fim de promover a participação e informar a população sobre a importância das referidas mudanças.

Retornando ao debate, em março de 2012, a Universidade Federal do Tocantins promoveu novas discussões no âmbito acadêmico produzindo um parecer técnico acerca do tema e intitulado Contribuições ao Debate sobre o Plano-Diretor de Palmas.

Esse documento, no que tange à ES 001/2012, discute a limitação da função principal das Áreas de Urbanização Específica. Na ES 001/2012 essas áreas seriam utilizadas para a criação das áreas de influência das rodovias, porém durante as discussões sobre o Plano Diretor, a função das Áreas de Urbanização Específica seria servir de instrumento de urbanização para promover a regularização fundiária das ocupações irregulares da cidade.

Outro ponto levantado na discussão diz respeito ao fato de que caso a ES 001/2012 fosse aprovada seria possível a construção de condomínios residenciais fechados nas margens da TO-010 e 050. Essa possibilidade desconsidera a função ambiental dessas áreas que funcionam como uma barreira física entre a cidade e a Área de Proteção Ambiental (APA) do Lajeado. Portanto a ocupação residencial das áreas de 
influência das rodovias seria inadequada porquanto incompatível com as questões de segurança ambiental.

Ao final, o documento, a fim de demonstrar a contribuição da instituição acerca do debate, apresenta várias propostas, dentre as quais se ressalta:

- $\quad$ Criar, por meio do Art. 17-A da Lei Complementar no 155, de 28 de dezembro de 2007, Áreas de Urbanização Específica e Área de Influência das Rodovias, separadamente, e não a primeira estar delimitada na faixa de terra da segunda.

- Criar Áreas de Urbanização Específica que atendam a critérios específicos para a regularização fundiária de ocupações atualmente consolidadas e de interesse social fora da área urbana da cidade.

- Deve permanecer como zona rural a Área de Influência das Rodovias, com o fim específico de atender aos empreendimentos de reduzidos impactos ambientais. Recomenda-se, então, a sua criação e a aprovação do Projeto de Lei que regulamenta o seu uso.

- Excluir, do inciso X do art. 23 da Lei Complementar no 155, de 28 de dezembro de 2007, o termo "condomínios residenciais fechados", haja vista que a delimitação da Área de Influência das Rodovias deverá permanecer como zona rural.

- Excluir do debate a criação da Zona de Expansão Urbana, tendo em vista a necessidade atual do adensamento da região central da cidade, a ser realizado com a utilização de mecanismos do Estatuto da Cidade, detalhados nas propostas encaminhadas na sequência deste documento. (Grifo nosso)

Ainda em âmbito acadêmico, foi realizado na UFT, também em março de 2012, o evento "Cidades Sustentáveis - Palmas em Foco" que contou com a presença do Professor Doutor Toshio Mukay o qual emitiu significativo parecer jurídico levantando a discussão acerca da legitimidade de iniciativa a projetos de lei que visem alterar o Plano Diretor.

A Lei Orgânica Municipal de Palmas (LOM), ao tratar das atribuições do Prefeito, dispõe no art. 71, VIII que cabe a este enviar à Câmara Municipal os projetos de lei dispondo sobre Plano Plurianual, Lei de Diretrizes Orçamentárias, Lei Orçamentária Anual e Plano Diretor. Nesses termos, a competência para iniciativa de projeto de lei sobre o Plano Diretor, bem como de suas respectivas alterações é do Executivo Municipal. Ademais, segundo o art. 42, IV da LOM, compete privativamente ao Prefeito a iniciativa dos projetos de lei que disponham sobre matéria orçamentária e de serviços públicos municipais.

Quanto à proposta de emendas a projetos de lei de iniciativa exclusiva do Executivo, dispõe o art. 44 da LOM que não serão admitidas emendas que visem ao aumento de despesa. Nesse sentido, o Professor Toshio Mukay esclarece que: 
Ora, qualquer emenda a projeto de lei que vá acrescentar ações executivas à Prefeitura, deverá aumentar a despesa orçamentária, e como está matéria é de exclusiva iniciativa do Prefeito, a emenda mencionada não será admissível. No caso presente, uma emenda da Câmara que pretenda criar uma zona ou área de expansão urbana, à evidência se criado, irá atrair a necessidade de gastos públicos com transporte, mobiliário urbano, serviços e equipamentos urbanos, antes inexistentes porque era área rural, e isto tudo deverá aumentar a despesa. (Grifo nosso).

Nesse sentido, em suas considerações o Professor Toshio Mukay ainda adverte que a disposição contida no art. 89 da LOM determina que a delimitação da zona urbana será definida por lei, observado o estabelecido no Plano Diretor. Logo, se é do Prefeito a iniciativa de lei para o Plano Diretor e ao longo de seu texto não consta nenhuma zona de expansão, então, não pode a Câmara Municipal alterar o Plano para contemplar a criação de uma área de expansão, de modo que isto iria configurar flagrante contrariedade ao Plano Diretor, bem como à LOM.

O debate acerca da expansão também se fortaleceu fora da Universidade e envolveu a participação de significativos grupos culminando na formação do Comitê "Contra a Expansão Urbana e a Favor da Regularização Fundiária" composto por representantes do Instituto de Arquitetos do Brasil - Seção Tocantins, do Curso de Direito da UFT, da Associação Nacional dos Engenheiros e Arquitetos da Caixa, do Sindicato dos Engenheiros do Estado do Tocantins, do Movimento Nacional de Luta Pela Moradia - MNLM, da Câmara de Vereadores de Palmas e de parte do empresariado.

Esse comitê, cuja finalidade era acompanhar e possibilitar um amplo debate a respeito dos projetos de alteração do Plano Diretor, formou uma comissão representante que se reuniu com o Prefeito em abril de 2012 solicitando a retirada dos PLCs № 06 e 07 para adequações, bem como da ES 001/2012. Esta solicitação fundamentou-se nas resoluções 008 e 009/2012 editadas pelo Conselho de Desenvolvimento Urbano e Habitação e no Parecer Jurídico do Professor Toshio Mukay.

Entretanto, nenhuma destas mobilizações obteve êxito ante a determinação da Câmara Municipal de Vereadores em fazer expandir o perímetro urbano de Palmas. A ES 001/2012 dos PLCs № 06 e 07 continuou seu curso desconsiderando as propostas, pareceres e recomendações que apontavam para sua retirada, bem como pela realização de estudos técnicos e implementação de soluções mais viáveis e menos onerosas à população.

A indiferença da Câmara Municipal ante a postura contrária de vários segmentos instituídos na sociedade acarretou na provocação, por parte destes segmentos, do 
Ministério Público Estadual (MPE) que emitiu, em abril de 2012, a recomendação 001/2012 no sentido que de que o Prefeito Municipal retirasse os referidos projetos de pauta para que fossem discutidos os aspectos legais quanto a sua continuidade em face da nova lei 12.608/2012 e também que fosse obedecida a iniciativa do Poder Executivo Local para a propositura de projetos de lei de alteração do Plano Diretor.

A fim de consubstanciar a necessidade e relevância de sua intervenção no debate acerca da expansão urbana da cidade, o MPE, na emissão da recomendação supracitada, faz uma série de considerações importantes como a necessidade de observância do Estatuto da Cidade que estabelece normas de ordem pública e interesse social que regulam o uso da propriedade urbana em prol do bem coletivo, a necessidade de adequação das disposições acerca da elaboração e alteração Plano Diretor às diretrizes estabelecidas pela União, a determinação do Estatuto da Cidade da necessidade de realização de promoção de audiências públicas e debates com a participação da população e de associações representativas dos vários segmentos da comunidade. Ademais o MPE considerou ser obrigatória a observação das mudanças impostas pela Lei 12.605/2012.

Nesse sentido, o MPE resolveu recomendar Câmara Municipal o seguinte:

RESOLVE RECOMENDAR:

1) Ao Presidente da Câmara dos Vereadores de Palmas - TO que suspenda imediatamente a realização das audiências públicas noticiadas na imprensa para discussão de alterações no Plano Diretor desta Capital, e não as realize enquanto não cumpridas as formalidades legais, especialmente as da Lei 12.608.

Em resposta à recomendação do MPE, o Município limitou-se a justificar a inaplicabilidade da Lei 12.608/12 porquanto o PLC № 06 já tramitava à época da edição da MP 547/11 posteriormente convertida na referida lei. Sob tais argumentos, prosseguiuse a discussão dos PLCs nº 06 e 07 e a ES 001/2012 sendo realizada pela Câmara de Vereadores, em abril de 2012, a primeira audiência pública para discutir o referido projeto.

Essa postura do Legislativo Municipal foi como um "dar de ombros" à participação da sociedade representada por instituições coletivas tão significativas da comunidade palmense como a Universidade Federal do Tocantins, o Conselho Municipal de Desenvolvimento Urbano e Habitação de Palmas e o próprio Ministério Público Estadual.

A irredutibilidade do Prefeito e da Câmara de Vereadores ante as propostas, solicitações, pareceres e recomendações que apontavam para a necessidade de suspensão do trâmite dos PLC s no 06 e 07 e da ES001/2012 não deixou outra 
alternativa, senão a busca de meios coercitivos mediante o Poder Judiciário. Nesse contexto, o Ministério Público Estadual e o Instituto de Arquitetos do Brasil- Departamento do Tocantins propuseram ações buscando o contrapeso do Poder Judiciário para fazer 'frear' os Poderes Legislativo e Executivo Municipal.

\subsection{Manobras legislativas para fomento da especulação imobiliária}

Os PLCs no 06 e 07 e a respectiva ES 001/2012 ficaram paralisados ante a polêmica em torno da expansão urbana da cidade, bem como pela manifestação contrária de importantes órgãos de representação dos interesses populares até culminar na proposição de ações civis públicas que pleiteavam a suspensão dos referidos projetos.

Entretanto, no auge das discussões, O Executivo Municipal aproveita a parte do texto da ES 001/2012 que altera o art. 19 e 43 e a coloca no PLC no 12 que é rapidamente aprovado pela Câmara Municipal, originando a LC nำ253/12. A pretensão do Prefeito de reproduzir a proposta encabeçada pelo Líder de Governo na Câmara é facilmente identificada no quadro abaixo:

\begin{tabular}{|c|c|}
\hline $\begin{array}{l}\text { Proposta de alteração do Líder de } \\
\text { Governo quando da elaboração da ES 001/2012 }\end{array}$ & $\begin{array}{l}\text { Proposta de alteração do PCL no } 12 \\
\text { apresentada pelo Executivo Municipal }\end{array}$ \\
\hline Art. & 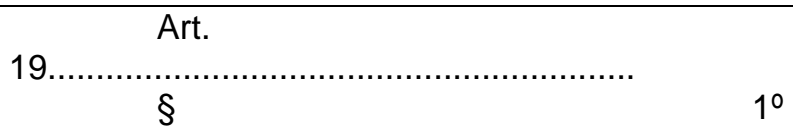 \\
\hline $2^{\circ}$ & $2^{\circ}$ \\
\hline $\begin{array}{l}\S 3^{\circ} \text { As áreas definidas neste Plano } \\
\text { Diretor e nos parcelamentos do solo como áreas } \\
\text { públicas municipais não poderão ter sua } \\
\text { destinação fim e objetivos originalmente } \\
\text { estabelecidos alterados, exceto: } \\
\text { I - para a implantação de equipamentos } \\
\text { públicos; } \\
\text { II - quando houver relevante interesse } \\
\text { público ou administrativo devidamente justificado; } \\
\text { III - quando não mais se justificar } \\
\text { urbanisticamente seus fins e objetivos } \\
\text { originalmente previstos. }\end{array}$ & $\begin{array}{l}\S 3^{\circ} \text { As áreas definidas neste Plano } \\
\text { Diretor e nos parcelamentos do solo como áreas } \\
\text { públicas municipais não poderão ter sua } \\
\text { destinação fim e objetivos originalmente } \\
\text { estabelecidos alterados, exceto: } \\
\text { I - para a implantação de equipamentos } \\
\text { públicos; } \\
\text { II - quando houver relevante interesse } \\
\text { público ou administrativo devidamente justificado; } \\
\text { III - quando não mais se justificar } \\
\text { urbanisticamente seus fins e objetivos } \\
\text { originalmente previstos. }\end{array}$ \\
\hline $\begin{array}{l}\text { §10 As áreas definidas neste Plano } \\
\text { Diretor e parcelamentos do solo, como áreas } \\
\text { verdes, não poderão ter sua destinação fim e } \\
\text { objetivos originalmente estabelecidos alterados, } \\
\text { exceto nas seguintes condições: } \\
\text { I- quando sobre a área houver relevante } \\
\text { interesse público ou administrativo devidamente }\end{array}$ & $\begin{array}{l}\text { \$10 As áreas definidas neste Plano } \\
\text { Diretor e parcelamentos do solo, como áreas } \\
\text { verdes, não poderão ter sua destinação fim e } \\
\text { objetivos originalmente estabelecidos alterados, } \\
\text { exceto nas seguintes condições: } \\
\text { I - quando sobre a área houver } \\
\text { relevante interesse público ou administrativo }\end{array}$ \\
\hline
\end{tabular}




\begin{tabular}{|c|c|}
\hline 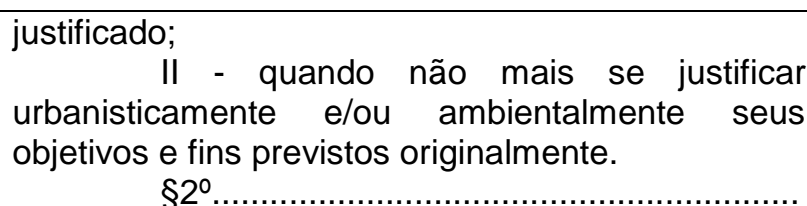 & $\begin{array}{l}\text { devidamente justificado; } \\
\text { II - quando não mais se justificar } \\
\text { urbanisticamente e/ou ambientalmente seus } \\
\text { objetivos e fins previstos originalmente. } \\
\$ 2^{\circ}\end{array}$ \\
\hline$\S 3^{\circ}$ & 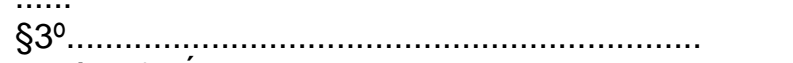 \\
\hline Parágrafo Único - .................................... & 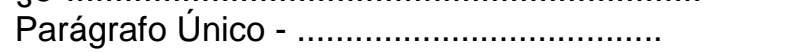 \\
\hline
\end{tabular}

Essas alterações foram acrescidas à Lei 155/07, por meio da aprovação da LC 253/12, e possibilitaram ao Executivo Municipal a alteração do uso e a desafetação das APMs sem qualquer participação da população, bem como a desafetação das áreas verdes da cidade por mera discricionariedade administrativa.

Esse entendimento é asseverado por Bazolli (2012):

Pode-se afirmar que a Emenda Substitutiva 001/2012 atacada na Ação Pública impetrada pelo MPE, não subsiste no mundo jurídico, razão pela qual não poderia fundamentar a LC 253/2012 que foi aprovada em junho passado. Absurdamente a nova lei retrocede e vai de encontro a Constituição Federal e Estatuto da Cidade, pois, retira a audiência pública para alteração de destinação das Áreas Públicas Municipais no Art. 19, enquanto em relação às Áreas Verdes, além do desrespeito aos mesmos diplomas legais mencionados, amplia suas consequências por confrontar protocolos internacionais e agendas nacionais, especialmente a Agenda 21. As Áreas Verdes que não poderiam ter sua destinação fim e objetivos alterados em qualquer hipótese passam às mãos do poder público, que poderá alterá-las por meio de razões subjetivas e frágeis. (Grifo nosso)

Passados apenas 5 (cinco) dias da aprovação da LC nำ 253/12, o Executivo Municipal submete à Câmara de Vereadores, ainda em junho de 2012, o PLC nำ 13 que autoriza a desafetação, alteração de uso, de ocupação do solo e de nomenclaturas de aproximadamente 70 (setenta) áreas públicas incluídas áreas verdes sob o argumento de que todas essas áreas não mais seriam consideradas servíveis ao uso da municipalidade. Todas essas áreas encontram-se dentro do Plano Diretor de Palmas e têm localização privilegiada como a Praça 05 na ACSU SO 50, a Praça da ACSU SE 20, a Praça ACSU SE 60, dentre várias outras. Em sua justificativa, o Prefeito afirma ainda que estas áreas não fariam falta ao Município, uma vez que o Plano Diretor de Palmas dispõe de várias outras áreas destinadas á equipamentos públicos.

Outro expressivo argumento utilizado pelo Executivo Municipal para justificar a 
decisão unilateral de desafetar APMs e áreas verdes foi a arrecadação de receitas que, por meio de alienações onerosas, seriam prioritariamente destinadas a contrapartidas de programas habitacionais e de infraestrutura já contratados pelo Município.

A par de todos esses fatos, o CAU/TO propôs, em setembro de 2012, a Ação Direta de Inconstitucionalidade das Leis Complementares Municipais no 253/12 e 255/12 sob $\mathrm{o}$ argumento de que estes diplomas legais contemplavam vícios formais e materiais. A ação, inicialmente proposta perante o Judiciário Estadual, prossegue em discussão na Justiça Federal.

\section{CONSIDERAÇÕES FINAIS}

A simples observação dessa sequencia de fatos demonstra a obstinação do poder público para praticar e fomentar a especulação imobiliária e impulsionar a segregação social. As práticas de retenção de áreas centrais, a serem adquiridas por valores altos, e a doação de regiões periféricas para moradia de pessoas de baixa renda, estão presentes desde a fundação de Palmas e se reproduzem fazendo persistir a perversa especulação imobiliária tão excludente e tão combatida pelo direito urbanístico.

A especulação imobiliária nega a função social da propriedade e da cidade, gera exclusão social e encarece o custo de urbanização. Esse fenômeno de produção do capital imobiliário baseia-se num conceito de propriedade absoluta desconsiderando os preceitos constitucionais de relativização da do direito de propriedade em prol do bem comum.

O que se infere é que a questão urbana de Palmas nada tem haver com a falta de espaços, mas sim com quem pode ser o dono de certos espaços. Prova disso é a proposta do Executivo de desafetação de mais de setenta áreas públicas, localizadas no Plano Diretor, para alienação onerosa. Enquanto isso a cidade planejada continua com imensos vazios urbanos, com terrenos não edificados aguardando a valorização imobiliária sem que para isso seus proprietários tenham qualquer gasto. Em contraste com essa realidade, a população de baixa renda se vê impelida a popular as áreas periféricas da cidade desprovidas da infraestrutura necessária. 


\section{REFERÊNCIAS}

BAZOLLI, João Aparecido. Dispersão urbana e instrumentos de gestão: dilemas do poder local e da sociedade em Palmas/TO. Universidade Federal de Uberlândia, Minas Gerais: 2012; p. 336. Disponível em:

$<$ http://www.researchgate.net/publication/235446164 Disperso Urbana e Instrume ntos de Gesto Dilemas do poder local e da sociedade em PalmasTO?ev=prf pub> Acesso em: 20 out. 2014.

. Lei 10.257, de 10 de julho de 2001. Regulamenta os arts. 182 e 183 da Constituição Federal, estabelece diretrizes gerais da política urbana e dá outras providências. Brasília, 2001. Disponível em:

<http://www.planalto.gov.br/ccivil_03/leis/LEIS_2001/L10257.htm>. Acesso em: 20 nov. 2013.

CORIOLANO, Germana Pires. Palmas: entre o planejamento e a exclusão. Vitruvius: Arquitextos. Disponível em:

<http://www.vitruvius.com.br/revistas/read/minhacidade/11.122/3587> Acesso em: 25 nov. 2013.

GRUPO QUATRO. Plano Diretor de Palmas. Palmas, 1988. Disponível em: <http://www.grupoquatro.com.br/site/>. Acesso em: 10 janeiro. 2014.

MUKAI, T. Parecer jurídico sobre a Expansão do Plano Diretor de Palmas. In Cidades Sustentáveis - Palmas em foco. Palmas, 2012.

PREFEITURA MUNICIPAL DE PALMAS. Lei Municipal no 1.384, de 06 de setembro de 2005 Cria o Conselho de Desenvolvimento Urbano e Habitação de Palmas, 2005. Disponível em:

<http://legislativo.palmas.to.gov.br/media/leis/LEI\%200RDINARIA\%20N\%C2\%BA\% 201384\%20de\%2003-10-2005\%2015-53-4.pdf>. Acesso em: 12 jan. 2012.

. Lei Orgânica do Município de Palmas. Disponível em:

<http://legislativo.palmas.to.gov.br/media/leis/LEI\%20ORGANICA\%20N\%C2\%BA\%2 000\%20de\%2005-04-1990\%2015-16-16.pdf> Acesso em 10 fev. 2014.

. Lei Complementar no 155, de 28 de dezembro de 2007. Dispõe sobre o Plano Diretor Participativo do Município de Palmas. Palmas, 2007. Disponível em:<http://legislativo.palmas.to.gov.br/media/leis/LEI\%20COMPLEMENTAR\%20N\% C2\%BA\%20155\%20de\%2028-12-2007\%2011-53-26.pdf>. Acesso em: 12 jan. 2012.

Secretaria de Desenvolvimento Urbano, Meio Ambiente e Habitação (2014). Dados sobre a densidade populacional de Palmas. Disponível em: <http://srvsefin.palmas.to.gov.br/portalprefeitura/servicos/seduh/> Acesso em: 10 fev. 2014.

SEGAWA, Hugo. Palmas, cidade nova ou apenas uma nova cidade? Projeto: Revista Brasileira de Arquitetura, Planejamento, Desenho Industrial e Construção, s. I.: n. 146, p. 94-109, out. 1991. 
SIQUEIRA, Frankes Marcio Batista; VILARINHO NETO, Cornélio Silvano. O capital imobiliário e a cidade - uma análise do espaço urbano de Cuiabá como resultado da preparação para a Copa do Mundo de 2014. Rev. Acta Geográfica, v. 6 , n. 13 (2012). Disponível em:

<http://revista.ufrr.br/index.php/actageo/article/view/1144> Acesso em 15 dez. 2013.

TEIXEIRA, Luís Fernando Cruvinel. A formação de Palmas. Dossiê cidades planejadas na Hinterlândia. Revista UFG: Junho. Ano XI, no 6, 2009; p. 91-99 Disponível em: <http://www.proec.ufg.br/revista ufg/junho2009/Palmas.pdf>. Acesso em: 25 de novembro de 2013. 